\title{
Media Independence And Firm Performance: Evidence From Emerging Stock Markets
}

Omar Farooq, American University in Cairo, Egypt

\begin{abstract}
Can media have any influence on firm performance? Do firms in countries with more independent media perform better than firms with less independent media? This paper seeks to answer these questions and aims to document the relationship between media independence and firm performance in emerging markets. Using a dataset from twenty-four emerging markets, we show a significantly positive relationship between media independence and firm performance. We argue that independent media reduces information asymmetries for stock market participants. Consequently, it becomes hard for managers to expropriate, thereby improving performance of firms. We also show that the relationship between media independence and firm performance is more pronounced in firms that have higher agency problem. For instance, our results show stronger impact of media independence on firms with no dividend payouts, no analyst coverage, concentrated ownership, and higher level of operational complexity. It shows that media can play a substitute for traditional governance mechanisms in emerging markets.
\end{abstract}

Keywords: Media Independence; Firm Performance; Emerging Markets

\section{INTRODUCTION}

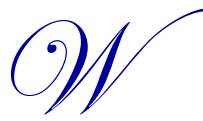

hy do firms headquartered in certain countries outperform similar firms headquartered in certain other countries? Is performance a function of the extent of agency problems present within a firm? Given the relationship between agency problems and firm performance, the answers to the above questions have formed the basis for plentiful of prior literature (Mitton, 2002; Johnson et al., 2000). Most of this literature revolves around understanding how firm-specific and country-specific proxies for agency problems; i.e., corporate governance mechanisms, effect firm performance. Johnson et al. (2000), for example, show that countryspecific measures of corporate governance are positively related to firm performance in emerging markets. They argue that firms headquartered in poor governance environments have a higher likelihood of being expropriated by managers/controlling shareholders. As a result, they do not perform as well as firms headquartered in better governance environments. In another related study, Mitton (2002) documents significantly better stock price performance for firms associated with better firm-specific measures of corporate governance. He shows that firms with higher disclosure quality (ADRs and auditors from big-six accounting firms) and higher outside ownership concentration outperform other firms. An important factor that has been overlooked in the prior literature is how independence of media - country-specific proxy for information asymmetry - affects performance of firms. Media is a channel through which information is communicated and disseminated to a wider audience. Effective and independent media plays an important role in reducing information asymmetries by making people aware of the events happening around them. Consequently, an independent media addresses the principal-agent problem and establishes a process of accountability for forces in power. Given media's role in reducing information asymmetry, it is worthwhile to see whether it impacts firm performance or not. This paper is an attempt to fill the gap by documenting the relationship between the two.

This paper argues that one of the channels via which media independence exercises its influence on firm performance is through its impact on information environment of a firm. Our conjecture is consistent with prior 
literature that relates media independence with better governance and disclosure mechanisms. Prior literature documents a strong link between media independence and governance environment of a firm. Dyck and Zingales (2002), for instance, consider media as an important channel via which external stakeholders can pressurize managers and directors to act in the best interest of shareholders. In another related study, Kahan and Rock (2007) come to the same conclusion when they show that media pressure is an important enabling tool that can force firms to adopt good governance practices. Dyck et al. (2007) argue that coverage of misconducts of management in media increases the probability that these misconducts will be stopped. This strand of literature identifies a couple of channels via which media plays its disciplining role, the most important being its effect on reputation of managers and firms. Fama (1980) argues that manager's future wages are an increasing function of shareholders' and future employers' beliefs about whether a manager will attend to their interests in situations where they cannot be monitored. Fama and Jensen (1983) note that the concerns regarding future monetary consequences can lead managers to act in the best interest of shareholders. For reputational concerns to reduce expropriation, the information about unscrupulous behavior of management must be publicized in the media. Prior literature highlights a number of examples when media attention resulted in disciplining managers. SK Telecom, for example, is an interesting case where media campaign not only helped in stopping expropriation, but also forced the firm to improve its corporate governance practices. In another case, the Board of Directors of Sears \& Roebuck succumbed to the ad campaign launched against their inappropriate behavior (Monks and Minnow, 1995).

Consistent with prior literature, this paper argues that firms headquartered in countries with more independent media should have better governance environments than similar firms headquartered elsewhere. As a result, these firms should outperform firms headquartered in countries with less independent media. Our arguments are consistent with prior literature that shows a strong link between firm performance and its governance environment. Lemmon and Lins (2003), for example, show that stock returns of firms in which managers have a high level of control rights, but lower cash flow ownership, are significantly lower than other firms. In another related study, Gompers et al. (2003) find that stock returns of firms with strong shareholder rights outperform returns of firms with weak shareholder rights. These studies argue that better governance practices minimize agency problems and do not allow managers to expropriate. Consequently, performance of the firms goes up. Consistent with our expectations, this paper documents a significantly positive relationship between media independence and firm performance in a large dataset from twenty-four emerging markets. Our results show that for every unit increase in media independence, firm performance goes up by 0.4430 basis points. We argue that countries with more independent media have better information environment than countries with less independent media. As a result, firms headquartered in countries with more independent media have lower agency problems. Eventually, lower agency problems translate into better performance of these firms.

In addition, we also show that media is more important in determining performance of firms that have higher agency conflicts. For example, our results show a significantly positive impact of media independence on performance of firms that pay no dividends. No dividend payout is considered as a proxy for poor governance because it indicates that managers may have more cash at hand to expropriate or to expense on unprofitable projects (Jensen, 1986). Our results show that for every unit increase in media independence, firm performance goes up by 0.7537 basis points for these firms. We argue that media acts as a substitute for traditional governance mechanisms for these firms. In contrast to firms that pay no dividends, our results show no impact of media independence on performance of firms that pay dividends. Furthermore, our results show that every unit increase in media independence causes firm performance to go up by 0.4430 basis points for a group of firms with analyst coverage and 2.0696 basis points for a group of firms without analyst coverage. No analyst coverage is an indication of poor information environment or lower investor interest. Therefore, these firms are supposed to have higher agency problems (Chung and Jo, 1996; Chen and Steiner, 2000). This result also indicates that media can act as a substitute for traditional governance mechanisms. Consistent with previous results, we show that media significantly influences performance of firms with concentrated ownership and firms with high operational complexity. Both of these groups are supposed to have higher agency problems. Our results show that for every unit increase in media independence, performance of concentrated ownership firms goes up by 0.6509 basis points and performance of high operational complexity goes up by 0.4393 basis points. In contrast to these firms, our results show no impact of media independence on performance of firms with dispersed ownership and firms with lower operational complexity. These results further support our claim that media can act as a substitute for traditional governance mechanisms in emerging markets. 


\section{DATA}

This paper documents the relationship between media independence and firm performance in twenty-four emerging stock markets from various parts of the world. The sample contains emerging markets from Latin America (Argentina, Brazil, Chile, Colombia, Peru, Mexico, and Venezuela), Asia-Pacific (Indonesia, Malaysia, Thailand, South Korea, Taiwan, and Philippines), South Asia (India, Pakistan, and Sri Lanka), Europe (Israel, Turkey, Greece, Poland, Czech Republic, Hungary, and Russia), and Africa (South Africa). The sample period for this study is 1999. The choice of sample period is driven by the availability of data regarding media independence. We describe our dataset in the following subsections.

\section{Media Independence}

We measure media independence (MEDIA) by the average proportion of market share of private entities in $\mathrm{TV}$ and press within a certain country. The data for the proportion of market share of private entities in TV and press is obtained from Shleifer et al. (2003). We use the data provided by Shleifer et al. (2003) to construct a measure for media independence as follows. Farooq and Dandoune (2012) also used the same measure to document the relationship between media independence and dividend policies in emerging markets:

$$
M E D I A=\frac{1}{2}\left(\begin{array}{l}
\text { Proportionof market share of privateentities in TV } \\
+ \text { Proportionof market share of private entities in Press }
\end{array}\right)
$$

We believe that if ownership of media is concentrated in the hands of governments, there is a lower likelihood that it will provide objective and credible information. A state-owned media is usually more inclined to distort and manipulate information to benefit politicians, prevent voters and consumers from making informed decisions, and ultimately undermine the markets. Waisboard (1995), while studying the role of media in Latin America, documents that government officials benefit more from state-controlled media than the public. We believe that private ownership of media results in provision of alternative views to the public, thereby enabling them to choose among alternatives. It is in contrast to state ownership where only single view is presented to audience. Shleifer et al. (2003), our source of data on media independence, study patterns of media ownership in 97 countries and show that countries that are poorer, more autocratic, and have higher levels of state intervention in the economy also have greater state ownership of the media. They also show that countries with greater state ownership of the media have a less-free press, inferior governance, and less-developed capital markets. Moreover, we argue that private ownership allows for competition among media firms, thereby ensuring that the public will get unbiased and accurate information. Failing to act responsibly or colluding may harm media's credibility and profitability in the long run. Table 1 documents media independence in each country. The results show that Mexico, Peru, and Turkey are the countries with the most independent media. These countries have a media that is completely owned by private sector. Our results also show that South Africa has the least independent media with only $35 \%$ of the media in the hands of private sector. These results must have changed by now due to privatization and deregulation of media in most of the emerging markets.

Table 1: Descriptive Statistics For Media Independence

\begin{tabular}{|l|c|}
\hline \multicolumn{1}{|c|}{ Countries } & Media Independence \\
\hline Argentina & 98.00 \\
\hline Brazil & 94.50 \\
\hline Chile & 70.50 \\
\hline Colombia & 86.50 \\
\hline Czech Republic & 83.00 \\
\hline Greece & 80.00 \\
\hline Hungary & 90.00 \\
\hline India & 56.00 \\
\hline Indonesia & 81.00 \\
\hline Israel & 82.00 \\
\hline South Korea & 61.50 \\
\hline Malaysia & 56.50 \\
\hline \multicolumn{2}{|c|}{ 2013 The Clute Institute } \\
\hline \multicolumn{2}{|c|}{ Copyright by author(s) Creative Commons License CC-BY }
\end{tabular}




\begin{tabular}{|l|c|}
\hline Mexico & 100.00 \\
\hline Pakistan & 50.00 \\
\hline Peru & 100.00 \\
\hline Philippines & 69.50 \\
\hline Poland & 71.50 \\
\hline Russia & 44.50 \\
\hline South Africa & 35.00 \\
\hline Sri Lanka & 45.00 \\
\hline Taiwan & 68.50 \\
\hline Thailand & 70.00 \\
\hline Turkey & 100.00 \\
\hline Venezuela & 98.50 \\
\hline
\end{tabular}

\section{Firm Performance}

This paper measures performance of a firm by the market-adjusted returns (RET). The market-adjusted returns are the difference between stock returns and market returns. Stock prices and market index are used to calculate the market-adjusted returns. We extract the stock price data and the corresponding market index data from Datastream. The stock price data and the market index data were obtained for the first and last days of our sample period to compute the market-adjusted returns.

\section{METHODOLOGY}

This paper aims to test whether media independence is related to a firm's performance or not. In order to answer this question, we estimate a cross-sectional regression with firm performance (RET) as a dependent variable and media independence (MEDIA) as an independent variable. For the purpose of completeness, we also include industry dummies (IDUM) and region dummies (RDUM) in our regression equation. It is important to mention here that our construction of media variable (MEDIA) is such that we have unique value of media ownership for almost every country in the sample (except Thailand and Peru where $100 \%$ of media is in the hands of private entities). As a result, it is not possible to include country dummies. Therefore, we include region dummies to account for any effects specific to the geography of the firm. We classified our firms to be located in five regions; namely, Latin America, Asia-Pacific, South Asia, Africa, and Europe. However, due to the presence of only one country in Africa, we combined Europe and Africa into one region. Our basic regression equation takes the following form:

$$
\begin{aligned}
& R E T=\alpha+\beta_{1}(M E D I A) \\
& +\sum_{\text {Ind }} \beta^{\text {Ind }}(I D U M)+\sum_{R g} \beta^{R g}(R D U M)+\varepsilon
\end{aligned}
$$

Mindful of the effects that firm-specific characteristics may have on firm performance, we also add a couple of firm-specific variables in our regression equation. For example, larger firms generate more interest from stock market participants and therefore have a better information environment. As a result, they may have better performance. Therefore, we add log of firm's market capitalization (SIZE) to capture the effect of size on performance. We also add total debt to total asset ratio (LEVERAGE) to capture the effect of leverage on firm performance. High-leverage firms have higher bankruptcy risk and therefore have lower performance. Similarly, earnings per share (EPS) and sales growth (GROWTH) were added to control for the effect of profitability and growth opportunities on firm performance. Profitable firms and firms with high growth opportunities tend to have better stock price performance. Our modified regression equation takes the following form.

$$
\begin{aligned}
& R E T=\alpha+\beta_{1}(\text { MEDIA }) \\
& +\beta_{2}(\text { SIZE })+\beta_{3}(\text { LEVERAGE })+\beta_{4}(\text { EPS })+\beta_{5}(G R O W T H) \\
& +\sum_{\text {Ind }} \beta^{\text {Ind }}(I D U M)+\sum_{R g} \beta^{R g}(R D U M)+\varepsilon
\end{aligned}
$$


The results of our analysis are reported in Table 2. Our results show that firms headquartered in countries with more independent media perform significantly better than firms headquartered in countries with less independent media. We report significantly positive coefficient of MEDIA for both equations. Our results from Equation (3) - the most comprehensive equation - show that for every unit increase in media independence, returns go up by 0.4430 basis point. We argue that firms headquartered in countries with more independent media have better information environment than firms headquartered in countries with less independent media. Therefore, these firms - those headquartered in countries with relatively more independent media - have lower agency problems. Consequently, there is lower likelihood of expropriations in these firms, thereby resulting in performance that is better than otherwise similar firms headquartered in countries with less independent media.

Table 2: Relationship Between Media Independence And Firm Performance

\begin{tabular}{|l|c|c|}
\hline & Equation (1) & Equation (2) \\
\hline MEDIA & $0.6464^{* * *}$ & $0.4430^{* *}$ \\
\hline SIZE & & $0.0375^{* * *}$ \\
\hline LEVERAGE & & 0.0002 \\
\hline EPS & & $-0.0016^{* * *}$ \\
\hline GROWTH & & -0.0001 \\
\hline & & Yes \\
\hline Industry Dummies & Yes & Yes \\
\hline Region Dummies & Yes & 2068 \\
\hline & & 5.30 \\
\hline No. Of Observation & 3044 & 0.033 \\
\hline F-value & 9.35 & \\
\hline Adjusted R & & \\
\hline
\end{tabular}

NOTE: The results significant at $10 \%$ significance level are followed by $*$, at $5 \%$ significance level by $* *$, and at $1 \%$ significance level by***.

\section{DISCUSSION OF RESULTS}

Some of the important questions that arise are:

1. Independent media is more effective for which firms? Is it for firms that already have better information environments or is it for those that have higher information asymmetries?

2. Does independent media compliment a governance environment or substitute for a governance environment?

We aim to answer these questions by re-estimating Equation (3) for sub-samples representing different governance and information regimes.

\section{Media Independence And Firm Performance Under Different Dividend Policies}

For the purpose of this paper, we define dividend policy by a firm's decision whether or not to pay dividends. Prior literature considers dividend policy as a mechanism via which firms can reduce agency problems. Grossman and Hart (1980), for instance, argue that high dividend payouts alleviate agency conflicts through the reduction of free cash flow available to managers. In another related study, Jensen (1986) concludes that high payout ratio can lessen the agency costs by reducing free cash flow that could be expensed on unprofitable projects. This strand of literature argues that paying high dividends reflects management's good faith and signals lower agency problems. Our results from re-estimation of Equation (3) are reported in Table 3. Our results show that media has no impact on firm performance for a sample of firms that pay dividends. We report insignificant coefficient of MEDIA for this group. However, we show a significantly positive impact of media independence on performance of firms that pay no dividends. We report significantly positive coefficient of MEDIA for this group. Our results show that for every unit increase in media independence, firm performance goes up by 0.7537 basis points for this group. Our results indicate that where information asymmetries are already low, media does not have any value-enhancing 
impact. However, it acts as a substitute for traditional governance mechanisms for firms that do not have a better governance environment.

Table 3: Relationship Between Media Independence And Firm Performance Under Different Dividend Policies

\begin{tabular}{|l|c|c|}
\hline & Firms With Dividends & Firms Without Dividends \\
\hline MEDIA & 0.3178 & $0.7537^{* *}$ \\
\hline SIZE & & $0.0350^{* *}$ \\
\hline LEVERAGE & $0.0251^{* *}$ & 0.0009 \\
\hline EPS & 0.0002 & -0.0010 \\
\hline GROWTH & $-0.0019^{* * *}$ & -0.0008 \\
\hline & 0.0006 & Yes \\
\hline Industry Dummies & & Yes \\
\hline Region Dummies & Yes & 792 \\
\hline & Yes & 6.89 \\
\hline No. Of Observation & & 0.114 \\
\hline F-value & 1276 & 2 \\
\hline Adjusted R & 2.53 & \\
\hline
\end{tabular}

NOTE: The results significant at $10 \%$ significance level are followed by $*$, at $5 \%$ significance level by $* *$, and at $1 \%$ significance level by***.

\section{Media Independence And Firm Performance Under Different Levels Of Analyst Coverage}

Financial analysts are the agents that provide an independent assessment of a firm's performance beyond what is provided in financial statements. They constantly upgrade their assessments by unearthing new information about the firms. We argue that analysts help discipline managers because the market closely monitors forecasts and recommendations issued by them. As a result, the extent to which firms are mismanaged is likely to be lower for firms that are closely monitored by analysts (Chung and Jo, 1996; Chen and Steiner, 2000). On the other hand, when such monitoring is absent, managers may be more likely to pursue activities that benefit themselves at the expense of shareholders. In order to test whether the extent of analyst coverage affects the relationship between media independence and firm performance, we divide our sample into two groups - one with analyst coverage and the other without analyst coverage. We re-estimate Equation (3) for both groups and report our results in Table 4. As was the case before, we show that the relationship between media and firm performance is stronger in a group of firms with higher information asymmetries. We report a coefficient estimate of 0.4430 for a group of firms with analyst coverage and 2.0696 for a group of firms without analyst coverage. We argue that media acts as a substitute for governance mechanisms in a sample of firms with higher agency problems; i.e., firms without analyst coverage.

Table 4: Relationship Between Media Independence

And Firm Performance Under Different Levels Of Analyst Following

\begin{tabular}{|l|c|c|}
\hline & Firms With Analyst Coverage & Firms Without Analyst Coverage \\
\hline MEDIA & $0.4430^{* *}$ & $2.0696^{* * *}$ \\
\hline SIZE & & 0.0198 \\
\hline LEVERAGE & $0.0375^{* * *}$ & 0.0014 \\
\hline EPS & 0.0002 & 0.0014 \\
\hline GROWTH & $-0.0016^{* * *}$ & 0.0005 \\
\hline & -0.0001 & Yes \\
\hline Industry Dummies & & Yes \\
\hline Region Dummies & Yes & 736 \\
\hline & Yes & \\
\hline No. Of Observation & & \\
\hline F-value & 2068 & 0.127 \\
\hline Adjusted R & 5.30 & \\
\hline NOTE: Thesults & 0.033 & \\
\hline
\end{tabular}

NOTE: The results significant at $10 \%$ significance level are followed by $*$, at $5 \%$ significance level by $* *$, and at $1 \%$ significance level by***. 


\section{Media Independence And Firm Performance Under Different Ownership Structures}

Prior literature considers ownership structure as an important governance device. Concentrated ownership structures provide managers and controlling shareholders with means to evade effective disclosure of information (Leuz et al., 2003). Poor information disclosure exacerbates information asymmetries between insiders and outsiders and result in agency problems. Prior literature also suggests that high ownership concentration creates an entrenchment problem that allows controlling shareholders' self-dealings to go unchallenged by boards of directors. On the other hand, dispersed ownership structures reduce some of these agency problems by taking away powers from managers and insiders. In order to test whether ownership structure affects the relationship between media independence and firm performance, we divide our sample into two groups - one with concentrated ownership and the other with dispersed ownership. We define concentrated ownership as the case where insiders hold more than $50 \%$ of the shares and dispersed ownership as the case where insiders do not hold absolute majority. We re-estimate Equation (3) for both groups and report our results in Table 5. As was expected, we show no relationship between media independence and firm performance for dispersed ownership firms. Our results show insignificant coefficient of MEDIA for this group. On the other hand, our results for firms with concentrated ownership show a significant impact for media independence on firm performance. We show a significantly positive coefficient of MEDIA for this group. Our results show that for every unit increase in media independence, firm performance goes up by 0.6509 basis points for this group. As was mentioned before, we argue that media independence can play a governance role for firms where agency problems are high.

Table 5: Relationship between Media Independence and Firm Performance under Different Ownership Structures

\begin{tabular}{|l|c|c|}
\hline & Concentrated Ownership & Dispersed Ownership \\
\hline MEDIA & $0.6509^{* * *}$ & -0.4358 \\
\hline SIZE & & $0.0509^{* *}$ \\
\hline LEVERAGE & $0.0405^{* * *}$ & 0.0011 \\
\hline EPS & -0.0001 & $-0.0029^{* * *}$ \\
\hline GROWTH & $-0.0011^{* *}$ & 0.0004 \\
\hline & -0.0002 & Yes \\
\hline Industry Dummies & & Yes \\
\hline Region Dummies & Yes & 396 \\
\hline & Yes & 3.46 \\
\hline No. Of Observation & & 0.089 \\
\hline F-value & 1671 & \\
\hline Adjusted $R^{2}$ & 4.91 & \\
\hline
\end{tabular}

NOTE: The results significant at $10 \%$ significance level are followed by $*$, at $5 \%$ significance level by $* *$, and at $1 \%$ significance level by***.

\section{Media Independence And Firm Performance Under Different Levels Of Operational Complexity}

Operational complexity of a firm intensifies agency problems and lowers information transparency. Prior literature maintains that operational complexity allows a broader scope to management for control (Abdel-Khalik, 1993). This strand of literature indicates that an increasing amount of complexity gives rise to moral hazard problems between the managers/controlling shareholders and minority shareholders. Knechel et al. (2008) argues that operational complexity eventually leads to manipulation of information by managers/controlling shareholders and thus increasing agency problems. We measure operational complexity by the ratio of salary expense to total operating expenses (Knechel et al., 2008). Consistent with our expectations, we document insignificant impact of media independence on firm performance for a sample of firms with low operational complexity and significantly positive impact of media independence on firm performance for a sample of firms with high operational complexity. Our results show that for every unit increase in media independence, firm performance goes up by 0.4393 basis points for this group. 
Table 6: Relationship Between Media Independence

And Firm Performance Under Different Levels Of Operational Complexity

\begin{tabular}{|l|c|c|}
\hline & High Complexity & Low Complexity \\
\hline MEDIA & $0.4393^{* *}$ & 0.1714 \\
\hline SIZE & & $0.0559^{* * *}$ \\
\hline LEVERAGE & $0.0305^{* * *}$ & 0.0001 \\
\hline EPS & -0.0001 & -0.0007 \\
\hline GROWTH & $-0.0020^{* * *}$ & 0.0009 \\
\hline & -0.0002 & Yes \\
\hline Industry Dummies & & Yes \\
\hline Region Dummies & Yes & 341 \\
\hline & Yes & 4.14 \\
\hline No. Of Observation & & 0.066 \\
\hline F-value & 1727 & 5.00 \\
\hline Adjusted R
\end{tabular}

NOTE: The results significant at $10 \%$ significance level are followed by $*$, at $5 \%$ significance level by $* *$, and at $1 \%$ significance level by***.

\section{CONCLUSION}

This paper explores the relationship between media independence and firm performance in twenty-four emerging markets from Latin America, Asia-Pacific, South Asia, Africa, and Europe. Our results show a positive relationship between media independence and form performance. We show that firms headquartered in countries with relatively more independent media perform significantly better than firms headquartered in countries with relatively less independent media. We argue that firms from countries with relatively more independent media have better information environment than their counterpart firms from countries with relatively less independent media. As a result, it is hard for managers to expropriate, thereby increasing firm performance in countries with relatively more independent media. Our results also show that media independence is more important for firms with higher agency problems. For example, we show stronger impact of media independence on firms with no dividend payouts, no analyst coverage, concentrated ownership, and higher level of operational complexity. It shows that media can play a substitute for traditional governance mechanisms in emerging markets.

\section{AUTHOR INFORMATION}

Omar Farooq is working as an Associate Professor of Finance at Aalborg University, Denmark. Before joining Aalborg University, he has also worked as an Assistant Professor of Finance at Al Akhawayn University in Ifrane, Morocco. His current research focuses is on corporate governance mechanisms in emerging markets, performance of analyst recommendations, and microfinance. E-mail: omar.farooq.awan@ gmail.com

\section{REFERENCES}

1. Abdel-Khalik, A. R., (1993). Why do Private Companies Demand Auditing? A Case for Organizational Loss of Control. Journal of Accounting, Auditing and Finance, 8 (1), pp. 31-52.

2. Chen, C. R. and Steiner, T. L., (2000). Tobin's Q, Managerial Ownership, and Analyst Coverage. Journal of Economics and Business, 52, pp. 365-382.

3. Chung, K. H. and Jo, H., (1996). The Impact of Security Analysts' Monitoring and Marketing Functions on the Market Value of Firms. Journal of Financial and Quantitative Analysis, 31, pp. 493-512.

4. Dyck, A. and Zingales, L., (2002). Corporate Governance Role of the Media. Working Paper 9309, National Bureau of Economic Research.

5. Dyck, A., Volchkova, N., and Zingales, L., (2007). The Corporate Governance Role of the Media: Evidence from Russia. Working Paper, University of Toronto.

6. Fama, E. F., (1980). Agency Problems and the Theory of the Firm. Journal of Political Economy, 88(2), pp. 288-307. 
7. Fama, E. F. and Jensen, M. C., (1983). Separation of Ownership and Control. Journal of Law \& Economics, 26(2), pp. 301-325.

8. Farooq, O. and Dandoune, S., (2012). Media Independence and Dividend Policy: Evidence from Emerging Markets. Forthcoming, Journal of Applied Business Research.

9. Gompers, P. A., Ishii, J. L., and Metrick, A., (2003). Corporate Governance and Equity Prices. Quarterly Journal of Economics 118 (1), pp. 107-155.

10. Grossman, S. and Hart, O., (1980). Disclosure Laws and Take-over Bids. Journal of Finance, 35, pp. 323334.

11. Jensen, M. C., (1986). Agency Costs of Free Cash Flow, Corporate Finance, and Takeovers. American Economic Review, American Economic Association, 76(2), pp. 323-329.

12. Johnson, S., Boone, P., Breach, A., and Friedman, E., (2000). Corporate Governance in the Asian Financial Crisis, 1997-98. Journal of Financial Economics, 58, pp. 141-186.

13. Kahan, M. and Rock, E. B., (2007). Hedge Funds in Corporate Governance and Corporate Control. University of Pennsylvania Law Review, 155.

14. Knechel, W. R., Niemi, L., and Sundgren, S., (2008). Determinants of Auditor Choice: Evidence from a Small Client Market. International Journal of Auditing, 12, pp. 65-88.

15. Lemmon, M. L. and Lins, K. V., (2003). Ownership Structure, Corporate Governance, and Firm Value: Evidence from the East Asian Financial Crisis. Journal of Finance, 58(4), pp. 1445-1468.

16. Leuz, C., Nanda, D., and Wysocki, P. D., (2003). Earnings Management and Investor Protection: An International Comparison. Journal of Financial Economics, 69(3), pp. 505-527.

17. Mitton, T., (2002). A Cross-firm Analysis of the Impact of Corporate Governance on the East Asian Financial Crisis. Journal of Financial Economics, 64, pp. 215-244.

18. Monks, R. and Minnow, N., (1995). Corporate Governance. Blackwell Publishers: Cambidge, MA.

19. Shleifer, A., Djankov, S., McLiesh, C., and Nenova, T., (2003). Who Owns the Media? Journal of Law and Economics, 46, pp. 341-382.

20. Waisbord, S., (1995). Leviathan Dreams: State and Broadcasting in South America. The Communication Review, 1(2), pp.201-226. 


\section{$\underline{\text { NOTES }}$}

